\title{
TATA KELOLA PEMBELAJARAN AKTIF, INOVATIF, KREATIF, EFEKTIF DAN MENYENANGKAN (PAIKEM) DI SMA PONDOK PESANTREN IMMIM MAKASSAR
}

\author{
H. MUH. AZHAR BURHANUDDIN \\ Fakultas Agama Islam \\ Universitas Muslim Indonesia Makassar
}

\begin{abstract}
:
From the results of research on the impact of PAIKEM is sure to help teachers in teaching and learning activities, because teachers are not too difficult in delivering materials and teachers enjoy in learning because students are active, students are directed to more creative develop creativity, teachers only more assess the results of student performance. Impact PAIKEM for Students, they feel more comfortable, friendly, easier for them to channel talent, easier to absorb the lesson because of this exciting atmosphere turned out to be more attention from the teacher who educates them. In line with the above statement, From the results of the research suggests that the positive impact of PAIKEM ie students will vigorously follow the teaching and learning activities because creative teachers create an atmosphere that students are actively creative, so it can make students confidently appear in front of the public.
\end{abstract}

Keywords: Active Learning, PAIKEM

\section{PENDAHULUAN}

\section{Latar Belakang Masalah}

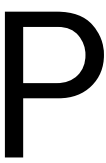

endidikan merupakan hak asasi setiap warga negara Indonesia dan untuk itu setiap warga Negara Indonesia berhak memperoleh pendidikan yang bermutu sesuai dengan minat dan bakat yang dimilikinya. Pemerataan akses dan peningkatan mutu pendidikan akan membuat warga negara Indonesia memiliki kecakapan hidup,sehingga mendorong tegaknya pembangunan manusia seutuhnya serta masyarakat yang dijiwai nilai-nilai pancasila, sebagaimana diamanatkan dalam UU No 20 Tahun 2003 tentang Sistem Pendidikan Nasional.

Dalam keseluruhan kegiatan Undang-Undang Republik Indonesia Nomor 20 Tahun 2003 Tentang Sistem Pendidikan Nasional pada pasal 1 menyebutkan; pendidikan adalah usaha sadar dan terencana untuk mewujudkan suasana belajar dan proses pembelajaran agar peserta didik secara aktif mengembangkan potensi dirinya untuk memiliki kekuatan spiritual keagamaan, pengendalian diri, kepribadian, kecerdasan, akhlak mulia, serta keterampilan yang diperlukan dirinya, masyarakat, bangsa dan Negara

Proses pendidikan menuju kearah pencapaian tujuan sebagaimana yang tertuang dalam Undang-Undang (UU) No. 20 Tahun 2003 tentang Sistem Pendidikan Nasional (Sisdiknas) Bab II pasal 3 yang berbunyi Pendidikan Nasional berfungsi mengembangkan kemampuan dan membentuk watak serta peradaban 
bangsa yang bermartabat dalam rangka mencerdaskan kehidupan bangsa, bertujuan untuk berkembangnya potensi peserta didik agar menjadi manusia yang beriman dan bertakwa kepada Tuhan Yang Maha Esa, berakhlak mulia, sehat, berilmu, cakap, kreatif, mandiri, dan menjadi warga negara yang demokratis serta bertanggung jawab.

Masalah yang dihadapi dunia pendidikan kita adalah masalah lemahnya proses pembelajaran. Dalam proses pembelajaran, anak kurang didorong untuk mengembangkan kemampuan berpikir. Proses pembelajaran di dalam kelas diarahkan kepada kemampuan anak untuk menghafal informasi, otak anak dipaksa untuk mengingat dan menimbun berbagai informasi tanpa dituntut untuk memahami informasi yang diingatnya itu untuk menghubungkannya dengan kehidupan sehari-hari. Akibatnya, ketika anak didik kita lulus dari sekolah, mereka pintar secara teoritis, tetapi mereka miskin aplikasi.

Kenyataan ini berlaku untuk semua mata pelajaran. Mata pelajaranSejarahmerupakan pembelajaran berpikir dan mengetahui sejarah, yang tidak digunakan secara baik dalam setiap proses pembelajaran di dalam kelas. Mata pelajaran Agama, tidak dapat mengembangkan sikap yang sesuai dengan norma-norma agama, karena proses pembelajaran hanya diarahkan agar anak bisa menguasai dan menghafalmateri pelajaran. Mata pelajaran Bahasa tidak diarahkan untuk mengembangkan kemampuan berkomunikasi, karena yang dipelajari lebih banyak membahas bahasa sebagai ilmu bukan sebagai alat komunikasi.

Gejala-gejala semacam ini merupakan gejala umum dari hasil proses pembelajaran. Proses pembelajarandi sekolah terlalu menjejali otak anak dengan berbagai bahan ajar yang harus dihafal; proses pembelajaran tidak diarahkan untuk membangun dan mengembangkan karakter serta potensi yang dimiliki; dengan kata lain, proses pembelajaran kita tidak pernah membentuk manusia yang cerdas, memiliki kemampuan memecahkan masalah hidup, serta tidak diarahkan untuk membentuk manusia yang kreatif dan inovatif.

Kuswadi (2011: 46) mengemukakan bahwa Pembelajaran merupakan suatu proses yang kompleks dan melibatkan berbagai aspek yang saling berkaitan. Oleh karena itu, untuk menciptakan pembelajaran yang kreatif dan menyenangkan diperlukan berbagai keterampilan. Di antaranya adalah keterampilan membelajarkan atau keterampilan mengajar. Untuk kepentingan tersebut, guru harus memiliki pengetahuan yang luas mengenai jenis-jenis belajar, serta kondisi internal dan eksternal peserta didik, dan juga menciptakan pembelajaran aktif, inovatif, kreatif, efektif dan menyenangkan (PAIKEM).

Dalam implementasi standar proses pendidikan, salah satu kemampuan yang harus di milikipendidik adalah bagaimana merancang suatu strategi pembelajaran yang sesuai dengan tujuan dan kompetensi yang akan di capai. Ada beberapa strategi yang dapat membantupendidik dalam merancang suatu pembelajaran salah satu diantaranya adalahstrategi PAIKEM (Pembelajaran Aktif, Inovatif, Kreatif, 
Efektif, dan Menyenangkan). PAIKEM merupakan salah satu strategi yang dapat diterapkan dalam kegiatan pembelajaran dimaksudkan dengan strategi karena bidang garapannya tertuju pada bagaimana cara (1) pengorganisasi materi pembelajaran (2) menyampaikan atau menggunakan metode pembelajaran, dan (3) mengelolah pembelajaran yang dikehendaki oleh ilmuan pembelajaran selama ini seperti Reigeluth dan Merill yang telah meletakkan dasar-dasar instruksional yang mengoptimalkan proses pembelajaran.

Strategi ini dapat membantupendidik dalam menerapkan suatu strategi pembelajaran pada bidang studiuntuk mengetahui manfaatnya dalam kehidupan keseharian. Anggapan ini timbul sebagai akibat pengalaman belajar sebelumnya lebih bersifat tekstual dan lebih menekankan pada penyelesaian soal-soal dari pada pembelajaran secara praktis. Pembelajaran yang dilakukan di kelas selama ini terkesan sifatnya monoton danpendidik sebagai satu-satunya sumber belajarditambah lagipemahaman peserta didik tentangilmu di asumsikan sebagaihafalan.

Bahan pembelajaran yang disampaikan tanpa memperhatikan penerapan strategi PAIKEM akan mempersulit bagi guru dalam mencapai tujuan pembelajaran. Pegalaman membuktikan bahwa kegagalan pembelajaran salah satunya disebabkan karena hanya memakai pembelajaran Kurikuler. Kelas yang kurang bergairah dan kondisi anak didik yang kurang kreatif karena penentuan model belajar yang kurang sesuai dengan sifat bahan dan tidak sesuai dengan tujuan pembelajaran. Karena itu, dapat dipahami bersama bahwa modelPAIKEM adalah suatu cara yang memiliki nilai strategis dalam kegiatan belajar mengajar. Nilai strategisnya adalah pengaplikasian langsung suatu materi dapat mempengaruhi jalannya kegiatan belajar mengajar.

Penerapan PAIKEM dilatarbelakangi oleh kenyataan bahwa model pembelajaran selama berlangsung ini cenderung membuat siswa merasa malas dan bosan dalam belajar, dimana siswa hanya duduk pasif mendengarkan guru berceramah, tanpa memberikan reaksi apapun kecuali mencatat dibuku tulis atas apa yang diucapkan oleh guru mereka. Hal ini berakibat pada kurang optimalnya penguasaan materi pada diri peserta didik

Berdasarkan pemikiran di atas diharapkan sebuah proses pembelajaran mutlak diperlukan adanya Tata kelola PAIKEM yang baik. Yakni, (1)Terencana, (2)Terlaksana dan (3) Evaluasi Proses dan Evaluasi Hasil. Hal ini di maksudkan agar pembelajaran tidak berlangsung seadanya. Pembelajaran haruslah berlangsung dengan terencana untuk mengetahui apa faktor-faktor yang mendukung dan faktor-faktor penghambatnya. Kemudian dampaknya kepada guru maupun kepada siswa. Salah satu pembelajaran yang belakangan ini mencuat, dan di akui sebagai strategi pembelajaran yang inovatif serta dapat menjadi solusi atas kemonotonan pembelajaran di kelas adalah PAIKEM. Hal ini menjadi pertimbangan utama bagi penulis untuk melakukan penelitian dengan judul "Tata Kelola 
Pembelajaran Aktif, Inovatif, Kreatif, Efektif dan Menyenangkan (PAIKEM) Di SMA Pondok Pesantren IMMIM Makassar".

\section{Rumusan Masalah}

Bertitik tolak dari latar belakang penelitian yang telah dikemukakan di atas, maka rumusan masalah adalah sebagai berikut:

1. Bagaimana Perencanaan Tata Kelola PAIKEM Di SMA Pondok Pesantren IMMIM Makassar?

2. Bagaimana Pelaksanaan Tata Kelola PAIKEM Di SMA Pondok Pesantren IMMIM Makassar?

3. Bagaimana Evaluasi Tata Kelola PAIKEM Di SMA Pondok Pesantren IMMIM Makassar?

4. Apakah Faktor Pendukung dan Faktor Penghambat Tata Kelola PAIKEM Di SMA Pondok Pesantren IMMIM Makassar?

5. Apakah Dampak Pelaksanaan PAIKEM terhadap Guru dan Siswa Di SMA Pondok Pesantren IMMIM Makassar?

\section{Tujuan Penelitian}

Merujuk pada rumusan masalah yang telah diuraikan di atas, maka tujuan yang ingin dicapai dari penelitian ini adalah sebagai berikut:

1. Untuk Mengetahui Perencanaan Tata Kelola PAIKEM Di SMA Pondok Pesantren IMMIM Makassar.

2. Untuk Mengetahui Pelaksanaan Tata Kelola PAIKEM Di SMA Pondok Pesantren IMMIM Makassar.

3. Untuk Mengetahui Evaluasi Tata Kelola PAIKEM Di SMA Pondok Pesantren IMMIM Makassar.

4. Untuk Mengetahui Faktor Pendukung dan Faktor Penghambat Tata Kelola PAIKEM SMA Di Pondok Pesantren IMMIM Makassar.

5. Apakah Dampak Pelaksanaan PAIKEM terhadap Guru dan Siswa Di SMA Pondok Pesantren IMMIM Makassar

\section{Manfaat Penelitian}

Manfaat dari penelitian ini dapat diklasifikasikan menjadi dua macam yaitu:

1. Manfaat Teoritis

Hasil penelitian ini dapat dijadikan sebagai acuan dalam pengembangan Tata kelola PAIKEM.

2. Manfaat PraktisHasil penelitian ini diharapkan dapat bermanfaat bagi:

a. Sekolah

Dapat memberikan sumbangan nyata kepada pengelola sekolah khususnya kepala sekolah dalam rangka penerapan Tata kelola pembelajaran 
b. Guru

Sebagai bahan kajian untuk meningkatkan profesionalisme guru dalam mengelolah pembelajaran, dan mengetahui faktor-faktor yang menjadi pendukungdan penghambat dalam proses pembelajaran.

c. Siswa

Mempermudah siswa dalam memahami konsep dan nilai yang terkandung dalam materi sehingga berkontribusi terhadap pembentukan karakter positif, yang tentu sangat berguna baik masih berada di sekolah maupun saat terjun ke masyarakat termasuk dunia kerja.

d. Peneliti

Penelitian ini dapat memberikan pengalaman langsung kepada peneliti dalam mengembangkan tata kelola PAIKEM.

\section{TINJAUAN PUSTAKA}

\section{Tata Kelola Pembelajaran}

\section{Pengertian Tata Kelola}

Tata kelola (Management) berasal dari kata to manage yang artinya mengatur. Pengaturan dilakukan melalui proses dan diatur berdasarkan urutan dan fungsi-fungsi Tata kelola. Maka dapat dipahami melaluipengertian Tata kelolasecara umum yang berarti mengkoordinasikomponen-komponen atau faktor-faktor pendukung organisasi demi pencapaian tujuan melalui pemberdayaan tenaga manusia, peralatan dan mesin-mesin.

Tata Kelola pembelajaran adalah suatu perencanaan atau suatu pola yang digunakan sebagai pedoman dalam merencanakan pembelajaran di kelas atau pembelajaran dalam tutorial dan untuk menentukan perangkat-perangkat pembelajaran termasuk diantaranya buku-buku, film, kurikulum, dan lain-lain. (Joyce,1992: 4).

Usman (2011: 5) sendiri mendefenisikan Tata kelola (Management) sebagai perencanaan, pengorganisasian, pengarahan dan pengendalian (P4) sumber daya organisasi untuk mencapai tujuan secara efektif dan efisien. Menurut Terry (Hasibuan 2001: 2) menyatakan bahwa Tatakelola (Management) adalah suatu proes yang khas yang terdiri dari tindakan-tindakan perencanaan, pengorganisasian, pengarahan dan pengendalian yang dilakukan untuk menentukan serta mencapai sasaran-sasaran yang telah ditentukan melalui pemanfaatan sumber daya manusia dan sumber-sumber lainnya. Sedangkan Koonts (Hasibuan 2001: 3) menyatakan bahwa Tatakelola (Management) adalah usaha mencapai suatu tujuan tertentu melalui kegiatan orang lain meliputi perencanaan pengergoniasasian, penempatan, pengarahan dan pengendalian.

Beberapa pendapat pakar diatas dapat disimpulkan bahwa Tatakelola (Management) adalah perpaduan ilmu dan seni yang didalamnya terdapat proses mengatur yang meliputi perencanaan, pengorganisasian, pengarahan dan 
pengendalian dalam mencapai tujuan tertentu. Persoalan penting dalam mengembangkan konsep Tatakelola(Management) adalah dimana para anggota organisasi saling mendukung tapi tidak sedikit juga jumlah kelompok yang saling menindas dalam rangka kepentingan masing-masing individu. Untuk itu dibutuhkanrasa tanggungjawab terhadap aktivitas atau tugas masing-masing.

\section{Fungsi-Fungsi Tata Kelola}

Setiap kegiatan yang dilakukan terdapat fungsi-fungsi Tatakelola (Management) yang menjadi acuan dalam pelaksanaan kegiatan, terdapat beberapa ahli manajemen yang berpendapat tentang fungsi-fungsi pokok manajemen.

Fayol(Kurniadin 2012: 36) fungsi-fungsi manajemen terdiri atasPlanning (perencanaan), organizing (pengorganisasian), commanding (pemberian perintah), coordination (mengkoordinasi) dan controlling (pengawasan). Sedangkan menurut Koontz (Kurniadin 2012: 37) fungsi-fungsi manajemen terdiri atas planning (perencanaan), organizing (pengorganisasian), staffing (penyusunan pegawai), controlling (pengawasan). Serta Terry (Kurniadin 2012: 38) menyatakan bahwa "fungsi-fungsi manajemen terdiri atas Planning, organizing, actuating, controlling".

Koontz \& O'Donnel (Mulyono 2008: 24) menyatakan bahwa manajer, dalammelakukan pekerjaan, harus melakukan kegiatan-kegiatan tertentu, yang dinamakan fungsi-fungsi manajemen, yang terdiri dari pertama Planning yang menentukan tujuan-tujuan yang hendak dicapai selama suatu masa yang akan datang dan apa yang harus diperbuat agar dapat mencapai tujuan-tujuan itu. Kedua Organizing yang mengelompokkan dan menentukan berbagai kegiatan penting dan memberikan kekuasaan untuk melaksanakan kegiatan-kegiatan itu. Ketiga Staffing yang menentukan keperluan-keperluan sumber daya manusia, menggerakkan, penyaringan, latihan dan pengembangan tenaga kerja. Keempat Directing yang berarti Penyusunan pegawai. Kelima Controling mengukur pelaksanaan dengan tujuan-tujuan, menentukan sebab-sebab penyimpangan dan mengambil tindakan-tindakan korektif dimana perlu. Fungsi-fungsi manajemen sesungguhnya melekat pada organisasi itu sendiri dimana diantaranya peramalan dalam manajemen, perencanaan dalam manajemen, pengorganisasi dalam manajemen, penggerakan dalam manajemen, pengawasan dalam manajemen dan evaluasi dalam manajemen. (Makmur, 2009: 97)

Dari beberapa pendapat tentang fungsi-fungsi manajemen yang dikemukakan oleh beberapa para ahli manajemen diatas maka secara garis besar dapat disimpulkan bahwa fungsi-fungsi manajemen terdiri atas perencanaan, pengorganisasian, penyusunan pegawai danpengawasan.

\section{Pentingnya Tata Kelola}

Tata kelola memiliki arti penting dalam mengatur segala sesuatu, karena kesuksesan sebuah organisasi atau suksesnya sebuah kegiatan itu tergantung dari 
cara pengelolaan organisasi atau kegiatan tersebut. Baik berawal dari perencanaannya, pengorganisasi, penerapannya, dan evaluasinya.

Menurut Kardi (2011: 8) Tata kelola pembelajaran mempunyai makna yang lebih luas dari pada strategi, metode atau prosedur.

Adapun beberapa ciri-ciri khusus pada strategi, metode atau prosedur yaitu:

a. Rasional teoritik logis yang disusun oleh para pencipta atau pengembangnya;

b. Landasan pemikiran tentang apa dan bagaimana siswa belajar (tujuan pembelajaran yang akan dicapai);

c. Tingkah laku mengajar yang diperlukan agar model tersebut dapat dilaksanakan dengan berhasil; dan

d. Lingkungan belajar yang diperlukan agar tujuan pembelajaran itu dapat tercapai.

\section{PAIKEM}

\section{Pengertian PAIKEM}

PAIKEM adalah sebuah pembelajaran yang memungkinkan peserta didik untuk mengerjakan kegiatan yang beragam dalam rangka mengembangkan keterampilan dan pemahamannya, dengan penekanan peserta didik belajar sambil bekerja, sementara guru menggunakan berbagai sumber dan alat bantu belajar termasuk pemanfaatan lingkungan, supaya pembelajaran lebih menarik, menyenangkan dan efektif.

Rusman (2013: 321) PAIKEM berasal dari konsep bahwa pembelajaran harus berpusat pada anak (student-centered learning) dan pembelajaran harus bersifat menyenangkan (learning is fun), agar mereka termotivasi untuk terus belajar sendiri tanpa diperintah dan agar mereka tidak merasa terbebani atau takut. Untuk itu, maka aspek fun is learning menjadi salah satu aspek penting dalam pembelajaran PAIKEM, di samping upaya untuk terus memotivasi anak agar mengadakan eksplorasi, kreasi, dan bereksperimen dalam pembelajaran.

PAIKEM dicanangkan oleh UNESCO dari empat pilar pendidikan:(1) learning to know, yaitu mempelajari ilmu pengetahuan berupa aspek kognitif dalam pembelajaran, (2) learning to do, yaitu belajar melakukan yang merupakan aspek pengamalan dan pelaksanaannya, (3) learning to be, yaitu belajar menjadi diri sendiri berupa aspek kepribadian dan kesesuaian dengan diri anak ini juga sesuai dengan konsep" multiple intelligence" dari Howard Gardne, dan (4) learning to life together, yaitu belajar hidup dalam kebersamaan yang merupakan aspek kesosialan anak, bagaimana bersosialisasi, dan bagaimana hidup toleransi dalam beragaman yang ada di sekeliling siswa.PAIKEM merupakan strategi pembelajaran dan menjadi pedoman dalam bertindak untuk mencapai tujuan yang telah ditetapkan. Dengan pelaksanaan PAIKEM, diharapkan berkembangnya berbagai macam inovasi kegiatan pembelajaran yang aktif, kreatif, efektif, dan menyenangkan. Pembelajaran merupakan implementasi kurikulum di sekolah dari 
kurikulum yang sudah dirancang dan menuntun aktivitas dan kreativitas guru dan siswa sesuai dengan rencana yang telah diprogramkan secara efektif dan menyenangkan. ini sesuai dengan yang dinyatakan oleh Brooks bahwa "pembaruan" dan "bagaimana guru mengajar", bukan dari ketentuan - ketentuan hasil"

Guru harus dapat mengambil keputusan atas dasar penilaian yang tepat ketika siswa belum dapat membentuk kompetensi dasar dan standar kompetensi berdasarkan intreaksi yang terjadi dalam kegiatan pembelajaran. Oleh karena itu, guru harus mampu menciptakan suasana pembelajaran partisipatif, aktif, kreatif, efektif, dan menyenangkan supaya kompetensi dasar dan standar kompetensi yang telah dirancang dapat tercapai.

\section{Kerangka Konsep}

Tata kelola pembelajaran PAIKEM dapat menarik perhatian peserta didik. Maka dalam proses PAIKEM dapat dilihat mulai dari Perencanaan, Pelaksanaan tahapan PAIKEM dan Evaluasi. Tata kelola pembelajaran PAIKEM dipengaruhi oleh dua faktor yaitu Faktor Pendukung dan Faktor Penghambat dalam pelaksanaannya. Dalam tata kelola pembelajaran PAIKEMpeserta didik mengerjakan kegiatan yang beragam dalam rangka mengembangkan keterampilan dan pemahamannya, dengan penekanan peserta didik belajar sambil bekerja, sementara guru menggunakan berbagai sumber dan alat bantu belajar termasuk pemanfaatan lingkungan, supaya pembelajaran lebih menarik, menyenangkan dan efektif.

Berdasarkan uraian tersebut, maka untuk mengetahui lebih jelas dibawah ini dikemukakan kerangka konseptual sebagai berikut:

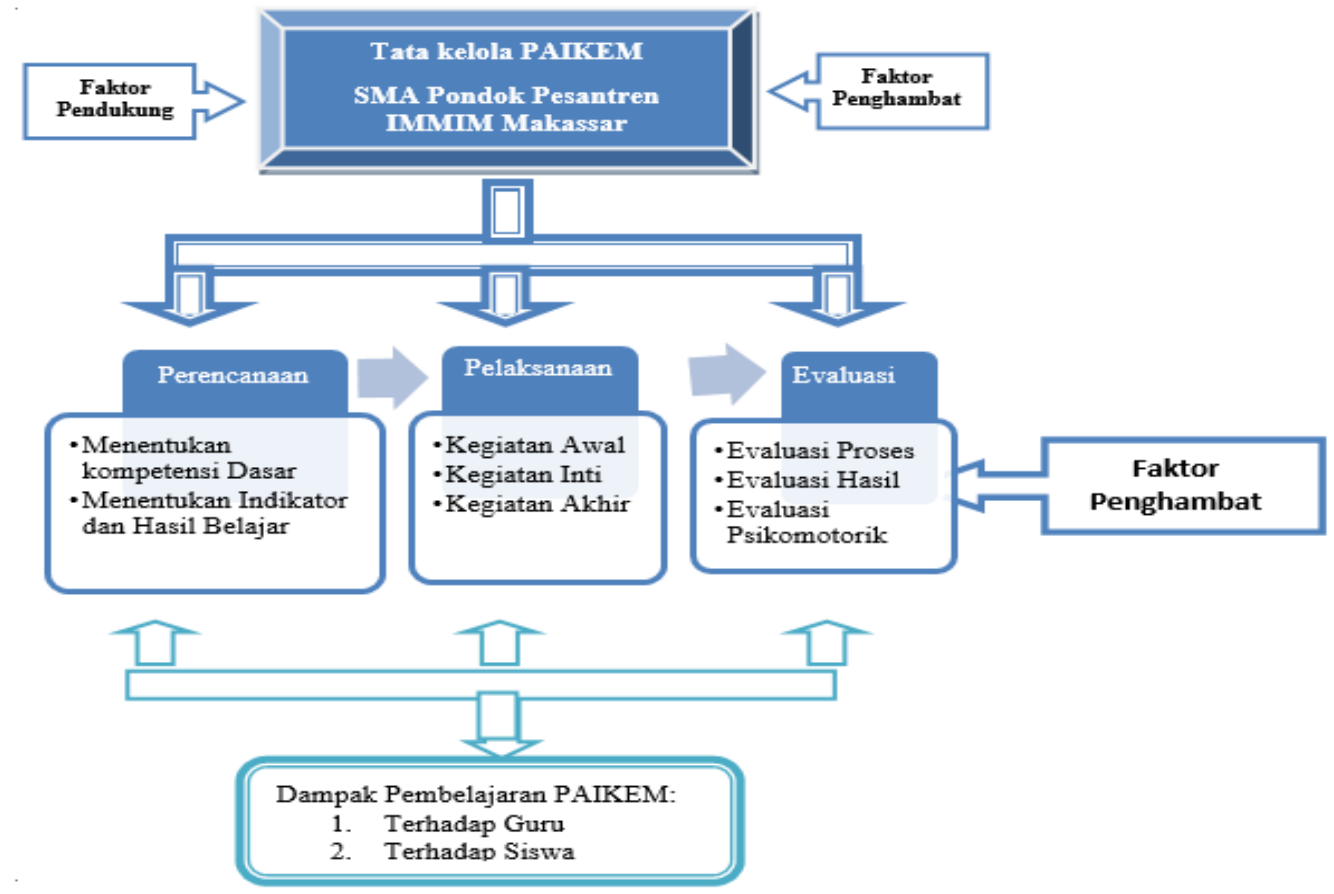

Gambar 2.2 Skema Kerangka Konsep Tata kelola PAIKEM 


\section{METODE PENELITIAN \\ Jenis Penelitian}

Penelitian ini adalah penelitian kualitatif yang menggunakan jenis deskriptif, yaitu jenis penelitian yang menggambarkan tentang suatu gejala, kondisi dan situasi yang ada. Penelitian ini akan mengungkap fenomena berdasarkan berbagai fakta yang ada dilokasi penelitian.

\section{Lokasi Penelitian}

Lokasi penelitian ini berada di Pondok Pesantren IMMIM Makassar.yang berlokasi di Jl. Perintis Kemerdekaan. KM.10 Makassar. Lokasi ini dipilih dengan pertimbangan bahwa data tersedia cukup lengkap yang menunjang penelitian ini, serta di Pondok Pesantren IMMIM belum pernah ada yang meneliti sebelumnya tentang tata kelola PAIKEM.

\section{Teknik Analisis Data}

Teknik analisis data yang digunakan dalam penelitian ini merupakan kegiatan yang bertujuan untuk mengolah data-data yang telah didapatkan oleh peneliti melalui kegiatan, Observasi,Wawancara,dan Analisis Dokumentasi.

\section{Reduksi Data}

Saat pengambilan data dilapangan dengan mewawancara sumber data utama, peneliti mencatat, merekam semua jawaban yang dikemukakan oleh sumber data, beragam data yang penulis peroleh. Ada jawaban yang sama, ada juga jawaban yang berbeda terhadap setiap pertanyaan yang diajukan. (Sugiyono 2012: 338)

Maka langkah yang dilakukan oleh peneliti yaitu melakukan analisis dengan mereduksi data, yakni merangkum semua hasil wawancara, hasil observasi dan studi dokumentasi, kemudian memilah dan mengambil hal-hal yang pokok, yang difokuskan pada permasalahan yang ingin dikaji oleh peneliti dengan berdasarkan pada indokator yang dikembangkan dalam pedoman wawancara yang terkait dengan Tata kelola PAIKEM di Pondok Pesantren IMMIM Makassar

\section{Menyajikan Data (Display Data)}

Langkah utama kedua dari kegiatan analisa data adalah penyajian data. Setelah mereduksi data sesuai dengan hal-hal yang pokok yang difokuskan pada permasalahan yang ingin dikaji, langkah selanjutnya adalah peneliti menyajikan data tersebut dalam bentuk narasi, artinya setiap fakta dan informasi yang didapatkan yang terjadi ataupun yang ditemukan peneliti, kemudian dinarasikan dan diberikan interpretasi terhadap fenomena-fenomena tersebut. (Sugiyono 2012: 341).

Hal ini dilakukan untuk memberikan pemahaman kepada peneliti mengenai fenomena yang terjadi, setelah itu peneliti merencanakan tindakan selanjutnya yang harus diambil berdasarkan pemaknaan terhadap fenomena tersebut. Data 
diolah dengan menyusun atau menyajikan data kedalam matriks yang sesuai dengan keadaan data yang berkenaan dengan Tata kelola PAIKEM di Pondok Pesantren IMMIM Makassar.

3. Verifikasi Data dan Penarikan Kesimpulan

Verifikasi data, pemeriksaan tentang kebenaran laporan/pernyataan responden. Verifikasi data dilakukan secara terus menerus sepanjang proses penelitian dilakukan. Sejak pertama kali memasuki lapangan dan selama proses pengumpulan data, penelitiberusaha untuk menganalisis dan mencari makna dari data yang dikumpulkan, yaitu mencari pola tema, hubungan persamaan, kesimpulan dan senjutnya dituangkan dalam bentuk kesimpulan yang masih bersifat naratif. Setelah data disajikan dan diverifikasi dalam bentuk naratif berdasarkan pemaknaan terhadap fenomena-fenomena yang terjadi dilapangan langkah peneliti selanjutnya adalah menarik kesimpulan bersadarkan pemaparan data tersebut. Penyimpulan data sesuai dengan fokus masalah. Kesimpulan yang diajukan sekaligus sebagai temuan penelitian. (Sugiyono 2012: 345)

\section{Teknik Pengabsahan Data}

Pemeriksaan keabsahan data merupakan tahap yang sangat penting dalam penelitian kualitatif, karena sangat menentukan tingkat kepercayaan terhadap hasil penelitian yang telah dilakukan dengan menggunakan uji kredibilitas. Aplikasi uji keabsahan secara jelas digambarkan sebagai berikut :

1. Triangulasi

Peneliti menggunakan berbagai teknik pengambilan data yakni: teknik observasi, wawancara dan dokumentasi dari berbagai sumber (orang, waktu, tempat) yang berbeda. Hal ini dilakukan untuk melihat kesesuaian data satu dengan data lainnya. Data yang diproleh dari observasi dicocokkan dengan informasi wawancara, berikut kesesuaiannya dengan dokumen yang ada, demikian juga pada sumber data yang berbeda. (Sugiyono 2012: 372)

\section{Meningkatkan Ketekunan}

Meningkatkan ketekunan berarti peneliti melakukan pengamatan secara lebih cermat dan berkesinambungan. Dengan cara tersebut maka kepastian data akan dapat diterima secara pasti dan sistematis. Ini dilakukan dengan cara membaca berbagai referensi buku maupun dokumentasi-dokumentasi yang terkait dengan temuan yang diteliti. Dengan membaca ini maka wawasan peneliti akan semakin luas dan tajam, sehingga dapat digunakan untuk memeriksa data yang ditemukan itu benar/dipercaya atau tidak. (Sugiyono 2012: 371)

\section{Member check}

Member check adalah proses pengecekan data yang diperoleh peneliti kepada pemberi data. Tujuan member check adalah untuk mengetahui seberapa jauh data yang diperoleh sesuai dengan apa yang diberikan oleh pemberi data. 
Apabila data yang ditemukan disepakati oleh pemberi data berarti data tersebut valid. Pelaksanaan membercheck dapat dilakukan setelah satu periode pengumpulan data selesai, atau setelah mendapat suatu temuan atau kesimpulan. (Sugiyono 2012: 375-376)

\section{HASIL PENELITIAN DAN PEMBAHASAN \\ Hasil Penelitian}

Berdasarkan hasil penelitian yang telah dipaparkan di atas, dapat diuraikan secara berturut-turut pembahasan hasil penelitian tentang tata kelola pembelajaran di SMA Pondok Pesantren IMMIM Makassar dengan fokus pada: (1) Perencanaan PAIKEM, (2) Pelaksanaan PAIKEM, (3) Evaluasi PAIKEM, (4) Faktor Pendukung dan Faktor Penghambat PAIKEM, (5) Dampak Pelaksanaan PAIKEM terhadap Guru dan Siswa.

\section{Gambaran Perencanaan Tata Kelola PAIKEM Di SMA Pondok Pesantren IMMIM Makassar.}

Perencanaan pembelajaran guru sudah memahami dan merangkaikan kegiatan yang tersusun secara sistematis, untuk mengarahkan seluruh kegiatan pembelajaran agar tujuan yang ditetapkan dapat tercapai dengan baik. Oleh karena itu, guru di SMA Pondok Pesantren IMMIM Makassar membuat perencanaan pembelajaran difungsikan sebagai pedoman dalam mendesain pembelajaran sesuai dengan kebutuhan. Perencanaan pembelajaran dijadikan pegangan yang sangat penting dalam pelaksanaan tugasnya sebagai pendidik dalam melayani kebutuhan belajar peserta didik untuk mencapai tujuan pembelajaran. Selain itu, perencanaan pembelajaran juga merupakan kegiatan awal yang dibuat guru sebelum proses pembelajaran.

Perencanaan pembelajaran yang dibuat oleh guru dapat diciptakan melalui perencanaan pembelajaran yang baik dan tepat. Pembuatan perencanaan pembelajaran yang baik, terarah, dan sistematis merupakan salah satu alat yang sangat dibutuhkan bagi guru di SMA Pondok Pesantren IMMIM Makassar untuk menciptakan pembelajaran yang maksimal. Guru-guru SMA Pondok Pesantren IMMIM Makassar akan selalu membuat perencanaan pembelajaran sebelum mengajar di depan kelas, dan tidak ada alasan mengajar tanpa perencanaan pembelajaran untuk mencapai tujuan dan standar kompetensi/kompetensi dasar, serta KKM yang telah ditetapkan.

Hal tersebut sesuai yang dikemukakan bahwa perencanaan adalah sejumlah kegiatan yang ditentukan sebelumnya untuk dilaksanakan pada suatu periode tertentu dalam rangka mencapai tujuan yang telah ditetapkan Usman (2008:60). Terry dan Leslie (2008:43) mengatakan bahwa perencanaan adalah proses memutuskan tujuan-tujuan apa yang akan dikejar selama jangka waktu yang akan datang dan apa yang dilakukan agar tujuan itu dapat tercapai. Sementara itu 
Malayu (2008:40) mengatakan bahwa perencanaan adalah penentuan tujuan dan pedoman pelaksanaan dengan memilih yang terbaik dari alternatif-alternatif yang ada.

Davis dalam Syarifuddin dan Nasution (2010:93) menyatakan bahwa perencanaan pengajaran adalah pekerjaan yang dilakukan oleh seorang guru untuk merumuskan tujuan mengajar. Sanjaya (2010:28) menyatakan perencanaan pembelajaran adalah proses pengambilan keputusan hasil berfikir secara rasional tentang sasaran dan tujuan pembelajaran tertentu, yakni perubahan perilaku serta serangkaian kegiatan yang harus dilaksanakan sebagai upaya pencapaian tujuan tersebut dengan memanfaatkan segala potensi dan sumber belajar yang ada.

\section{Gambaran Pelaksanaan Tata Kelola PAIKEM Di SMA Pondok Pesantren IMMIM Makassar.}

Guru melakukan proses pelaksanaan pembelajaran untuk implementasikan rencana pelaksanaan pembelajaran yang telah dirancang sebelumnya. Pelaksanaan pembelajaran guru mengutamakan pada pencapaian kompotensi dalam memperoleh pengetahuan, sikap, dan suatu keterampilan atau skill terhadap peserta didik.

Langkah-langkah kegiatan pelaksanaan pembelajaran yang dilakukan oleh guru mata pelajaran meliputi kegiatan tahap awal, kegiatan inti, dan kegiatan akhir atau penutup sesuai dengan amanat Peraturan Menteri Pendidikan Nasional Nomor 41 Tahun 2007 tentang Standar Proses untuk Satuan Pendidikan dasar dan Menengah lampiran Pemendiknas No. 41 Tahun 2007 angka romawi II huruf B, pelaksanaan pembelajaran merupakan implementasi dari rencana pelaksanaan pembelajaran. Pelaksanaan pembelajaran meliputi kegiatan pendahuluan, kegiatan inti dan kegiatan penutup.

Adapun indikator-indikator pelaksanaan pembelajaran yang diamati peneliti terhadap guru-guru meliputi: pada tahap awal yakni mengaitkan pelajaran sekarang dengan pelajaran sebelumnya, memberikan motivasi, menjelaskan tujuan pembelajaran, kemudian pada tahap kedua atau kegiatan inti yaitu memberikan pengantar materi, membagi siswa kedalam kelompok-kelompok belajar, mengingatkan cara siswa bekerja dan berdiskusi secara kelompok, mengarahkan untuk mempresentasikan hasil kegiatan, meminta kelompok lain menanggapi hasil presentasi, meluruskan Tanya jawab siswa, dan pada tahap akhir mengecek dan memberikan umpan balik, membimbing siswa menyimpulkan materi, memberi tugas rumah. Teori yang mendukung adalah Sagala (2009:26) mengatakan bahwa ada tiga tahap dalam strategi mengajar, yaitu tahap permulaan (prainstruksional), tahap pengajaran (instruksional), dan tahap penilaian dan tindak lanjut. Ketiga hal tersebut harus ditempuh pada setiap saat melaksanakan proses pengajaran. 


\section{Gambaran Evaluasi Tata Kelola PAIKEM Di SMA Pondok Pesantren IMMIM Makassar.}

Evaluasi yang dilaksanakan oleh guru dalam proses pengumpulan materi pelajaran untuk mengetahui pencapaian hasil belajar peserta didik. Evaluasi ini guru menganalisa sebagai bagian integrar dalam keseluruhan proses belajar mengajar. Penilaian harus dipandang sebagai salah satu faktor yang menentukan keberhasilan proses dan hasil pembelajaran, bukan hanya cara untuk menilai hasil belajar.

Senada dengan pendapat Siregar dan Nara (2011:141) menyatakan bahwa penilaian adalah suatu proses untuk mengambil keputusan dengan menggunakan informasi yang diperoleh melalui pengukuran hasil belajar, baik yang menggunakan instrument tes atau nontes.

Selanjutnya, Uno (2009:139) menyatakan bahwa evaluasi terhadap hasil belajar bertujuan untuk mengetahui ketuntasan dalam menguasai kompotensi dasar, indikator pencapaian dan hasil belajar. Dari hasil evaluasi tersebut dapat diketahui kompotensi dasar materi atau indikator yang belum mencapai ketuntasan. Dengan mengetahui hasil belajar, guru akan mendapatkan manfaat yang besar untuk melakukan perbaikan yang tepat.

Merujuk dengan Lampiran Pemendiknas No. 41 Tahun 2007 angka romawi IV, penilaian yang dilakukan oleh guru terhadap hasil pembelajaran untuk mengukur tingkat pencapaian kompotensi serta digunakan sebagai bahan penyusunan laporan kemajuan hasil belajar, dan memperbaiki proses pembelajaran.

Hasil penilaian yang dilakukan oleh guru secara konsisten, sistematis, dan terprogram dengan menggunakan tes dan nontes dalam bentuk tertulis atau lisan, penggunaan kinerja, pengukuran sikap, penilaian hasil pembelajaran menggunakan standar penilaian pendidikan dan panduan penilaian kelompok mata pelajaran.

Hasil Penilaian menunjukkan bahwa Dalam Evaluasi Afektif, Guru SMA Pondok Pesantren IMMIM Makassar sangat memperhatikan Sikap dan perilaku siswa dalam kegiatan belajar mengajar, Sikap diperhatikan dengan baik bahkan dinilai, karena banyak tingkah laku siswa yang akan muncul selama proses belajar mengajar, baik dan buruknya mesti dinilai oleh guru.

SMA Pondok Pesantren IMMIM Makassar Ujian MID maupun Ujian semester terjadwal dan terprogram dengan baik, jadi nilainya siswa lengkap dan disinilah dapat diketahui kemampuan dan perkembangan siswa dari nilai-nilainya. Ujian MID adalah gabungan dari beberapa RPP, mulai dari 1 sampai dengan RPP yang ke 6 , jadi Ujian MID terjadwal/ serentak semua mata pelajaran yang biasanya dilakanakan selama seminggu full.

Hasil praktek atau karya siswa diperhatikan, karena prinsipnya pembelajaran PAIKEM adalah mengaktifkan siswa \& membuat siswa lebih kreatif lagi. Itulah yang 
dikatakan kemampuan Psikomotoriknya. Jadi siswa kaya pengetahuan dan kaya aplikasii.

Pelaksanaan penilaian oleh guru SMA Pondok Pesantren IMMIM Makassar dilakukan untuk kegiatan penilaian sesuai dengan rencana yang telah disusun di awal kegiatan pembelajaran, untuk memeriksa aspek kognitif, afektif dan psikomotorik.

\section{Gambaran Faktor Pendukung dan Faktor Penghambat Tata KelolaPAIKEM Di SMA Pondok Pesantren IMMIM Makassar.}

\section{a. Faktor pendukung}

Faktor PendukungPAIKEM di Pesantren IMMIM yakni fasilitasnya memadai, mulai dari perpustakaan yang mempunyai buku-buku yang lengkap, laboratorium komputer, laboratorium bahasa dan ruang audiovisual, dan dilengkapi dengan laboratorium IPA yang memiliki banyak bahan praktek dan internet yang memakai Speedy.

Hal tersebut sejalan dengan pendapatFogarty (1991: 33) Faktor Pendukung Tata kelola PAIKEM adalah hal-hal yang dapat mendukung dan mempermudah pelaksanaan pembelajaran, Meliputi: Guru yang Kreatif, Sarana Prasarana Memadai, Buku paket, Buku panduan, Multi Media, Internet, Laktop, Perpustakaan, Ruang Audio Visual.

\section{b. Faktor Penghambat}

Faktor penghambat tata kelola PAIKEM adalah hal-hal yang merintangi dan menghambat pelaksanaan PAIKEM. Meliputi: Siswa yang bandel, Mata pelajaran yang banyak, Waktu yang kurang, Fasilitas Kurang dan Lingkungan itu sendiri.

Senada dengan pernyataan diatas, Bahwa kendalanya adalah jika siswa kurang merespon pembelajaran karena terlalu santai, materi pelajaran yang banyak lalu waktu terbatasi kemudian karena siswa diasramakan maka barang elektronik terbatasi dan jaringan internet yang kadang kurang lancar jadi itulah yang menjadi faktor penghambat. Karena jika jaringan yang kurang mendukung maka pembelajaran jadi terganggu, karena kita mengarahkan siswa untuk mengakses pengetahuan secara lebih luas.

\section{Gambaran Dampak Pelaksanaan PAIKEM terhadap Guru dan Siswa Di SMA Pondok Pesantren IMMIM Makassar.}

Dengan Strategi PAIKEM yang diterapkan dalam proses belajar mengajar, telah membuahkan hasil yang Positif bagi guru dan bagi siswa:

\section{a. Dampak PAIKEM bagi guru.}

Bagi Guru, selain lebih rileks, riang gembira, menambah ilmu pengetahuan lebih luas juga dapat membuat hati tenang dan awet muda sebab keseharian guru itu hanya bergelut dengan keceriaan, kasih sayang, sopan santun, dan penemuanpenemuan terbaru dari alam ilmu pengetahuan. (Fogarty, 1991: 33) 
Dari hasil penilitian tentang dampak PAIKEM yaknisangat membantu guruguru dalam kegiatan belajar mengajar, dikarenakan guru tidak terlalu sulit dalam menyampaikan materi dan guru enjoy dalam pembelajaran karena siswa yang aktif, siswa diarahkan untuk lebih kreatif mengembangkan kreatifitasnya, guru hanya lebih banyak menilai hasil kinerja siswanya.

\section{b. Dampak PAIKEM bagi siswa.}

Dampak PAIKEM bagi Murid, merekamerasa lebih nyaman, bersahabat, lebih mudah untuk mereka menyalurkan bakat, lebih mudah untuk menyerap pelajaran sebab dari suasana yang mengasyikkan ini ternyata siswa lebih mendapat perhatian dari sang guru yang mendidik mereka. (Fogarty, 1991: 33).

Senada dengan pernyataan diatas, Dari hasil penelitian siswa mengemukakan bahwa dampak positif dari PAIKEM yakni siswa akan penuh semangat mengikuti kegiatan belajar mengajar karena guru kreatif menciptakan suasana yang siswaaktif berkreasi, jadi dapat membuat siswa percaya diri tampil dihadapan khalayak ramai.

\section{KESIMPULAN DAN SARAN}

\section{Kesimpulan}

Berdasarkan hasil penelitian yang telah dilakukan oleh peneliti di SMA Pondok Pesantren IMMIM Makassarmengenai tata kelola PAIKEM, peneliti dapat mengambil kesimpulan sebagai berikut:

1. PerencanaanPAIKEM di SMA Pondok Pesantren IMMIM Makassar melalui tahapan Menentukan Kompetensi Dasar, Menentukan Indikator dan Hasil Belajar.

2. Pelaksanaan PAIKEM di SMA Pondok Pesantren IMMIM Makassaryang dilakukan dengan menggunakan tiga tahapan kegiatan , yaitu: Kegiatan Awal, Kegiatan Inti dan Kegiatan Akhir.

3. Evaluasi PAIKEM di SMA Pondok Pesantren IMMIM Makassar adalah proses dimana pelaksanaan dari pembelajaran diukur dan dinilai, yang dimaksud dalam penelitian ini adalah: Evaluasi Proses, Evaluasi Hasil dan Evaluasi Psikomotorik

4. Faktor Pendukung PAIKEMdan Faktor Penghambat Pembelajaran PAIKEM di SMA Pondok Pesantren IMMIM Makassar.

a. Faktor Pendukung Tata kelola PAIKEM adalah hal-hal yang dapat mendukung dan mempermudah pelaksanaan pembelajaran, Meliputi: Guru yang Kreatif, Sarana Prasarana Memadai, Buku paket, Buku panduan, Multi Media, Internet, Laktop, Perpustakaan, Ruang Audio Visual.

b. Faktor penghambat tata kelola PAIKEM adalah hal-hal yang merintangi dan menghambat pelaksanaan pembelajaran PAIKEM. Meliputi: Siswa yang bandel, Mata pelajaran yang banyak, Waktu yang kurang, Fasilitas Kurang 
dan Lingkungan itu sendiri.

5. Dampak Pelaksanaan PAIKEM di SMA Pondok Pesantren IMMIM Makassar terhadap Guru dan Siswa dalam Pembelajaran. Dengan Strategi PAIKEM yang diterapkan dalam proses belajar mengajar, telah membuahkan hasil yang Positif bagi guru dan bagi siswa:

a. Bagi Guru, selain lebih rileks, riang gembira, menambah ilmu pengetahuan lebih luas juga dapat membuat hati tenang dan awet muda sebab keseharian guru itu hanya bergelut dengan keceriaan, kasih sayang, sopan santun, dan penemuan-penemuan terbaru dari alam ilmu pengetahuan.

b. Sedangkan bagi Murid, merekamerasa lebih nyaman, bersahabat, lebih mudah untuk mereka menyalurkan bakat, lebih mudah untuk menyerap pelajaran sebab dari suasana yang mengasyikkan ini ternyata siswa lebih mendapat perhatian dari sang guru yang mendidik mereka.

\section{Saran}

Berdasarkan kesimpulan, Sebagai upaya untuk meningkatkantata kelolaPAIKEM, peneliti menyarankan beberapa hal sebagai berikut:

1. Kepada Guru SMA Pondok Pesantren IMMIM Makassar agar dalam penyusunan perencanaan PAIKEM senantiasa memperhatikan komponenkomponen penyusunan kompetensi dasar khususnya mengenai indikatorindikator pencapaian dan hasil belajar.

2. Kepada Guru SMA Pondok Pesantren IMMIM Makassar agar dalam pelaksanaan PAIKEM janganlah semua materi dibebankan kepada siswa kemudian guru mesti pintar dalam mengatur waktu pembelajaran agar materi pembahasan dapat selesai dalam sekali pertemuan.

3. Kepada Guru SMA Pondok Pesantren IMMIM Makassar agar dalam evaluasi PAIKEM guru dilengkapi dengan buku nilai agar nilai yang didapatkan oleh siswa adalah benar-benar nilai kemampuan siswa tersebut.

4. Kepada Pihak sekolah dan Yasdic IMMIM Makassar bahwa faktor pendukung dan penghambat tata kelola pembelajaran PAIKEM kebanyakan adalah dari Sarana dan Prasarana, guru dan siswa berharap fasilitas ditingkatkan, LCD disetiap ruangan, ruang Audio Visual ditambahkan dan Penambahan waktu dalam mengakses internet.

5. Karena Dampak PAIKEM sangatlah baik, maka siswa berharap semua guru mata pelajaran bisa menggunakan sistem pembelajaran PAIKEM. Karena sudah dibuktikan dengan mata pelajaran Sains, IPS, Agama dan Bahasa. 


\section{DAFTAR PUSTAKA}

Ahmadi, I.K \&Amri, S.2011. PAIKEM Gembrot (SebuahAnalisisTeoritis Konseptual, dan Praktis). Jakarta: Prestasi Pustaka.

Bafadal, I. 2003. Manajemen Peningkatan Mutu Sekolah Dasar: dari Sentralisasi menuju Desentralisasi. Jakarta: Bumi Aksara.

Departemen Pendidikan Nasional. 1996. Pembelajaran Terpadu D-11 PGSD dan S2 Pendidikan Dasar. Jakarta: Depdiknas.

.2007. Peraturan Pemerintah Republik Indonesia Nomor 41 Tahun 2007 tentang Standar Proses Untuk Satuan Pendidikan Dasar Dan Menengah. Jakarta: Balai Pustaka

Fogarty R. 1991. The Mindfull School: How to Interegrate the Curricula. Palatine, Illionis: Skylight Publishing Inc.

Gie, T.H. 2012. Pengantar filsafat ilmu Pendidikan. Yogjakarta: Liberty lif, K.A. \& Sofan, A. 2012. Paikem Gembrot. Jakarta: PT. Prestasi Pustaka raya.

Hartono, R. 2013. Ragam Model Mengajar yang Mudah Diterima Murid. Jogjakarta: DIVA Press.

Hamzah \& Nurdin, M. 2014. Belajar dengan Pendekatan PAILKEM. Jakarta: PT. Bumi Aksara.

Hasibuan. 2001. Manajemen: Dasar, Pengertian, dan Masalah. Jakarta: PT. Bumi Aksara.

Jamal, M. A. 2010. Tips Menjadi Guru Inspiratif, Kreatif, dan Inovatif. Jogjakarta: Diva Press.

Joyce. 1992. Models of Teaching, Fifth Edition. USA: Allyn and Bacon A Simon \& Scuster Company.

Kardi, K. 2003. Manajemen Aktual dan Professional dalam Dunia Bisnis dan Militer. Jakarta: Grasindo.

Kurniadin. 2012. Pendidikan: Konsep \& Prinsip Pengelolaan Pendidikan. Yogyakarta: Ar-Ruzz Media

Kuswadi. 2011. Menjadi Guru Profesional menciptakan Pembelajaran Kreatif dan Menyenangkan. Semarang: IAIN Walisongo.

Lou, A. J. 2009. Pengajaran yang Kreatif dan Menarik. PT Macanan Jaya Cemerlang.

Majid, A. 2009. Perencanaan Pendidikan. Bandung: PT. Remaja Rosdakarya.

Makmur .2009. Teori Manajemen Stratejik: Dalam Pemerintahan dan Pembangunan.Bandung: Refika Aditama

Malayu. 2008. Manajemen, Dasar, Pengertian dan Masalah. Jakarta: Bumi Aksara. 
Mulyasa, E. 2006. Kurikulum Tingkat Satuan Pendidikan (KTSP). Jakarta: Remaja Rosda karya.

Mulyono. 2008. Manajemen Administrasi \& Organisasi Pendidikan. Yogyakarta: ArRuzz Media

Purwanto, Evaluasi Hasil Belajar, Yogyakarta: Pustaka Belajar, 2004.

Rusman. 2013. Model-Model Pembelajaran. Jakarta: PT. Raja Grafindo Persada.

Roestiyah N. K. 2001. Strategi Belajar Mengajar. Jakarta: PT Rineka Cipta.

Sagala. S. 2010. Konsep dan Makna Pembelajaran. Bandung: Alfabeta.

Sanjaya, W. 2010. Strategi Pembelajaran (Beriorientasi Standar Proses Pendidikan). Jakarta: Kencana Prenada Media Group.

Sugiyono. 2012. Metode Penelitian Pendidikan. Bandung: Alfabeta.

Siregar, E \& Nara, H. 2011. Teori Belajar dan Pembelajaran. Bogor: Ghalia Indonesia.

Suyanto. 2013. Menjadi Guru Profesional. Makassar: Erlangga Redja.

Syarifuddin \& Nasution. I. 2010. Manajemen Pembelajaran. Jakarta: Quantum Teaching.

Taslimuharom. 2009. Metode Paikem Gembrot. Online: (http://hasanjoen.blogspot.com) Diakses 5 Januari 2015.

Terry, R.G. 2008. Prinsip-Prinsip Manajemen. Jakarta: Bumi Aksara.

Trianto. 2005. Model Pembelajaran Terpadu dalam Teori dan Praktik. Jakarta: Prestasi Pustaka.

Tiro, M. A. 2008. Dasar-dasar Statistika. Makassar: Andira Publisher.

Umaedi. 1999. Manajemen Peningkatan Mutu Berbasis Sekolah. Indonesia, Jakarta: Departemen Pendidikan dan Kebudayaan, Directorate Jenderal Pendidikan Dasar dan Menegah, Directorate Pendidikan Menengah Umum.

Undang-Undang RINomor 14 Tahun 2005. Guru dan Dosen. Jakarta: Sinar Grafika. 2008.

Undang-Undang RI Nomor 20 Tahun 2003.Sistem Pendidikan Nasional. Jakarta: Sinar Grafika. 2008.

Uno, H. B. 2009. Perencanaan Pembelajaran. Jakarta: Bumi Aksara.

Usman, Husaini, 2008. Manajemen Teori Praktik dan Riset Pendidikan. Jakarta: Bumi Aksara

Usman Uzer. Muh. 2011. Menjadi Guru Propesional. Bandung: PT. Remaja Rosdakarya.

Veithzal \& Sylviana. 2012. Education Management: Analisis Teori dan Praktik. Jakarta: Rajawali Pers. 